\title{
Kepatuhan Mengonsumsi Obat Pasien Hipertensi Di Denpasar Ditinjau Dari Kepribadian Tipe A Dan Tipe B
}

\author{
Putu Kenny Rani Evadewi \& Luh Made Karisma Sukmayanti S. \\ Program Studi Psikologi, Fakultas Kedokteran, Universitas Udayana \\ kennyrani@yahoo.co.id
}

\begin{abstract}
Abstrak
Perubahan gaya hidup masyarakat, seperti berkurangnya aktivitas fisik menyebabkan munculnya berbagai penyakit kronis salah satunya hipertensi. Pasien hipertensi diharuskan mengonsumsi obat secara teratur, sehingga diperlukan kepatuhan dalam mengonsumsi obat. Ada berbagai faktor yang mempengaruhi kepatuhan mengonsumsi obat, salah satunya adalah kepribadian. Kepribadian tipe A dan tipe B dikatakan memiliki hubungan erat dengan penyakit kronis. Penelitian ini bertujuan untuk mengetahui kepatuhan mengonsumsi obat pasien hipertensi di Denpasar ditinjau dari kepribadian tipe A dan tipe B.

Penelitian ini merupakan penelitian kuantitatif dengan metode komparasi. Teknik sampling yang digunakan yaitu purposive random sampling. Populasi dalam penelitian ini adalah pasien hipertensi di Denpasar dengan jumlah responden 267 subjek. Jumlah sampel dengan kepribadian tipe A adalah 135 subjek dan kepribadian tipe B sebanyak 132 subjek. Metode analisis data yang digunakan adalah independent sampel t test $(\mathrm{p}<0,05)$.

Hasil penelitian menunjukkan terdapat perbedaan kepatuhan mengonsumsi obat antara pasien hipertensi dengan kepribadian tipe A dan B (signifikansi p=0,001). Secara keseluruhan lebih didominasi subjek yang memiliki kepatuhan mengonsumsi obat buruk (189 orang) dibandingkan dengan subjek yang memiliki kepatuhan mengonsumsi obat baik (78 orang). Selain itu, hasil analisis kepatuhan mengonsumsi obat berdasarkan usia, jenis kelamin, lama mengalami hipertensi menunjukkan lebih banyak subjek berjenis kelamin laki-laki, berusia 52 hingga 59 tahun, mengalami hipertensi 6 sampai 10 tahun yang mungkin ikut berperan dalam kepatuhan mengonsumsi obat pada subjek.
\end{abstract}

Kata kunci: Kepatuhan mengonsumsi obat, kepribadian tipe A dan tipe B, hipertensi

\begin{abstract}
The changes of life style in today' such as reductions in physical activity led to the emergence of a variety of chronic diseases such for instance hypertension. Hypertensive patients are required to take medication on a regular basis, so that the necessary compliance in taking the drug. There are various factors that affect adherence taking the drug, one of which is personality. Personality type A and type B is said to have a close relationship with chronic disease. This study aims to determine the compliance of hypertensive patients taking the drug in Denpasar in terms of personality type A and type B.

This research is quantitative comparative method. Sampling technique used is purposive random sampling. The population in this study were hypertensive patients in Denpasar with the number of respondents 267 subjects. Number of samples with type A personalities are 135 subjects and type B personality as much as 132 subjects. Data analysis methods used are independent samples $t$ test $(\mathrm{p}<0,05)$.

The results indicate there are differences in medication adherence among hypertensive patients taking personality types $\mathrm{A}$ and $\mathrm{B}$ (significance $\mathrm{p}=0.001$ ). More respondents overall had a bad drug taking compliance (189 subjects) compared to subjects who had good adherence ( 78 subjects). Moreover, taking medication compliance analysis based on age, sex, duration of hypertension showed more male subjects, ages 52 to 59 years, with hypertension 6 to 10 years which may had a role in adherence patients taking medication.
\end{abstract}

Keywords: Compliance of medication consumption, type A and type B personalities, hypertension 


\section{LATAR BELAKANG}

Seiiring dengan adanya perubahan gaya hidup masyarakat seperti mengonsumsi makanan dengan kadar lemak tinggi, merokok, kegiatan yang tidak mengenal batas waktu, yang diiringi juga adanya kemajuan dalam bidang perdagangan dan teknologi seperti online shop. Hal ini berdampak pada pengurangan aktivitas fisik yang sehat seperti kurang bergerak dan sistem indera yang cenderung tidak digunakan secara maksimal. Pengurangan aktivitas fisik yang sehat berdampak munculnya berbagai penyakit kronis di masyarakat.

Aktivitas fisik individu tidak dapat dipisahkan dari penyakit kronis yang akan dialami individu, baik dalam pencegahan maupun pengobatan penyakit kronis. Aktivitas fisik ringan pada individu seperti terlalu lama duduk dapat menyebabkan penumpukan kolesterol total pada tubuh yang dapat meningkatkan risiko penyakit kronis. Salah satu pencegahan maupun pengobatan dari penyakit kronis adalah dengan olah raga secara teratur. Penyakit kronis merupakan penyakit yang memerlukan waktu lama, berbilang bulan atau tahun, untuk proses pengobatan (Arovah, 2011; Jaya, 2009).

Terkait proses pengobatan banyak masalah yang terjadi, khususnya pada penyakit kronis seperti masalah fisiologis yaitu pemakaian obat jangka panjang dapat menyebabkan terjadinya efek samping berupa kerusakankerusakan organ seperti pada hati, ginjal maupun organ lain. Selanjutnya masalah psikologis yaitu pemakaian obat jangka panjang membuat pasien penyakit kronis mengalami rasa tertekan. Hal ini dikarenakan pasien diwajibkan untuk mengonsumsi obat setiap hari dan adanya efek samping yang ditimbulkan obat yang dikonsumsi. Selain itu, masalah lingkungan keluarga ataupun masyarakat, yaitu seringkali keluarga atau masyarakat yang cenderung tidak mampu menerima keadaan pasien saat didiagnosis mengalami penyakit kronis. Masalah-masalah yang telah diuraikan di atas merupakan penyebab pasien penyakit kronis cenderung banyak yang tidak mematuhi proses pengobatan sesuai yang dianjurkan dan diberikan oleh tim medis, yang pada akhirnya memutuskan untuk berhenti mengonsumsi obat (Lailatusifah, 2012).

Ada berbagai macam penyakit kronis seperti tuberkulosis, diabetes mellitus, hipertensi dan lain sebagainya yang memerlukan kepatuhan pasien dalam mengonsumsi obat. Pada pasien tuberkulosis yang dianjurkan mengonsumsi obat secara rutin selama enam hingga delapan bulan, cenderung tidak mematuhi proses pengobatan yang dianjurkan oleh tim medis dan kembali lagi mengonsumsi obat jika tuberkulosis yang dialami mengalami kekambuhan atau mengalami keluhan fisik seperti batuk darah, nyeri dada, dan sesak nafas. Ketidakpatuhan dalam mengonsumsi obat juga banyak terjadi pada pasien diabetes mellitus dan hipertensi. Pada pasien diabetes mellitus seringkali kembali mengonsumsi obat jika timbul keluhan kesemutan atau mati rasa pada kaki dan tangan bahkan sampai tidak sadarkan diri (Siam, 2011; Dhewi, Armiyati, Supriyono, 2012; Wijayanti, 2012).

Hal serupa juga terjadi pada pasien hipertensi. Pasien hipertensi kembali mengonsumsi obat hipertensi jika timbul keluhan-keluhan seperti sakit kepala, jantung berdebar, dan penglihatan kabur (Jaya, 2009). Penyakit hipertensi merupakan penyakit kronis yang semakin meningkat baik di negara maju maupun negara berkembang termasuk Indonesia. Hipertensi di Indonesia merupakan penyakit dengan prevalensi tertinggi, dan sebagai penyebab utama kematian pada pasien. Banyak pasien yang tidak mengetahui mengalami hipertensi sehingga tidak ditangani dengan baik. Hasil Riset Kesehatan Dasar (Riskesdas) tahun 2007 menunjukkan sebagian besar kasus hipertensi belum terdiagnosis. Hal ini terlihat dari hasil pengukuran yaitu hanya $7,2 \%$ penduduk yang sudah mengetahui memiliki hipertensi dan hanya $0,4 \%$ kasus yang patuh minum obat hipertensi sehingga $76 \%$ dari masyarakat belum mengetahui mengalami hipertensi (Dimyanti, 2012; Kementerian Kesehatan Republik Indonesia, 2012). Hipertensi adalah keadaan tekanan darah pasien yang telah diukur menggunakan tensimeter dan diperoleh hasil tekanan sistolik diatas $140 \mathrm{mmHg}$ dan tekanan diastolik diatas $90 \mathrm{mmHg}$. Hipertensi tidak dapat disembuhkan namun hanya dapat dikendalikan melalui kontrol kesehatan secara rutin, melakukan diet rendah garam dan mengonsumsi obat secara teratur untuk mengurangi risiko komplikasi pada kardiovaskular dan organ lain yang ada pada diri pasien (Almisbah, 2008; Ratnaningtyas \& Djatmiko, 2011).

The Joint National Committee on prevention, detection, evaluation and treatment of high blood pressure $(J N C)$ membuat klasifikasi membagi hipertensi menjadi tingkat satu dan tingkat dua.

\begin{tabular}{l|c|c}
\multicolumn{2}{c}{ Tabel. 1. Klasifikasi Hipertensi } \\
\hline \multicolumn{1}{c|}{ Katagori } & $\begin{array}{c}\text { Tekanan Darah Sistolik } \\
\mathrm{MmHg}\end{array}$ & $\begin{array}{c}\text { Tekanan Darah Diastolik } \\
\mathrm{MmHg}\end{array}$ \\
\hline $\begin{array}{l}\text { Normal } \\
\text { Prehipertensi }\end{array}$ & $<120$ & $<80$ \\
Hipertensi & $120-139$ & $80-89$ \\
Stage 1 & $140-159$ & $90-99$ \\
Stage 2 & $\geq 160$ & $\geq 100$ \\
\hline \multicolumn{2}{c}{ Sumber : (Nafrialdi, 2007; Almisbah, 2008; Budiman \& Hafis, 2012) }
\end{tabular}

Faktor penyebab hipertensi dapat dibagi menjadi dua, yaitu faktor yang dapat dikontrol dan faktor yang tidak dapat dikontrol. Faktor yang dapat dikontrol yaitu, merokok yang merupakan salah satu faktor risiko yang kuat untuk terjadinya kematian akibat hipertensi. Penghentian merokok terbukti dapat mengurangi risiko mengalami hipertensi. Individu yang mengonsumsi satu batang rokok dapat terjadi peningkatan denyut jantung dan tekanan darah selama 15 menit. Faktor selanjutnya adalah obesitas. Berat badan individu dan indeks masa tubuh (IMT) berkorelasi langsung dengan tekanan darah, terutama tekanan darah sistolik. Obesitas bukanlah penyebab hipertensi. Akan tetapi prevalensi hipertensi pada obesitas 
jauh lebih besar. Individu dengan obesitas memiliki risiko lima kali lebih besar mengalami hipertensi. Pada pasien hipertensi ditemukan sekitar 20\% hingga 33\% memiliki berat badan yang berlebih. Faktor ketiga penyebab hipertensi yang dapat dikontrol adalah stres. Stres yang terjadi pada individu dapat merangsang kelenjar anak ginjal melepaskan hormon adrenalin dan memacu jantung berdenyut lebih cepat serta lebih kuat, sehingga tekanan darah akan meningkat. Jika stres berlangsung lama tubuh akan memunculkan gejala negatif seperti hipertensi (Jaya, 2009).

Faktor yang tidak dapat dikontrol terdiri dari jenis kelamin, dimana menurut pendapat Jaya (2009), laki-laki dianggap lebih rentan mengalami hipertensi dibandingkan perempuan. Hal ini dikarenakan gaya hidup yang lebih buruk dan tingkat stres yang lebih besar pada laki-laki dibanding perempuan. Faktor selanjutnya adalah usia pasien, dimana usia 45 tahun hingga 59 tahun dianggap mengalami kecenderungan hipertensi karena pada usia middle age merupakan usia dimana kondisi tubuh mulai menurun dan rentang mengalami penyakit kronis (Santrock, 2002). Faktor ketiga penyebab hipertensi yang tidak dapat dikontrol adalah riwayat keluarga. Individu yang keluarga atau orang tua mengalami hipertensi cenderung memiliki kemungkinan lebih besar mengalami hipertensi dibandingkan individu yang tidak memiliki keluarga yang mengalami hipertensi (Jaya, 2009).

Keberhasilan pengobatan pada pasien hipertensi dipengaruhi oleh beberapa faktor, salah satu di antaranya adalah kepatuhan dalam mengonsumsi obat, sehingga pasien hipertensi dapat mengendalikan tekanan darah dalam batas normal. Tetapi $50 \%$ dari pasien hipertensi tidak mematuhi anjuran petugas kesehatan untuk mengonsumsi obat, yang menyebabkan banyak pasien hipertensi yang tidak dapat mengendalikan tekanan darah dan berujung pada kematian pasien. Kepatuhan pasien dalam mengonsumsi obat dapat diukur menggunakan berbagai metode, salah satu metode yang dapat digunakan adalah Skala MMAS-8 (Morisky Medication Adherence Scale) yang terdiri dari tiga aspek yaitu frekuensi kelupaan dalam mengonsumsi obat, kesengajaan berhenti mengonsumsi obat tanpa diketahui oleh tim medis, kemampuan mengendalikan diri untuk tetap mengonsumsi obat (Morisky \& Munter, 2009).

Faktor-faktor yang mempengaruhi kepatuhan pasien hipertensi dalam mengonsumsi obat adalah faktor eksternal dan faktor internal. Faktor eksternal meliputi dampak pendidikan dan kesehatan, hubungan antara pasien dengan petugas kesehatan serta dukungan dari lingkungan sosial dan keluarga. Faktor internal meliputi usia, latar belakang, sikap dan emosi yang disebabkan oleh penyakit yang diderita, dan kepribadian pasien (Niven, 2002; Jaya, 2009; Feuer Stein, dkk. dalam Anggina dkk., 2010).

Hasil penelitian dari Pangesti (2013) menyatakan bahwa kepribadian memiliki korelasi signifikan dengan kepatuhan pasien dalam mengonsumsi obat, terutama kepribadian tipe A dan tipe B yang memiliki ciri-ciri yang bertolakbelakang. Kepribadian tipe A yang memiliki sifat terburu-buru, jiwa pesaing kuat, perfeksionis, polyphasic, dan kepribadian tipe B memiliki sifat santai, jiwa pesaing rendah, monophasic, dan tidak perfeksionis. Kepribadian tipe A memiliki kecenderungan lebih besar untuk mengidap penyakit kronis karena dari sifat kepribadian tipe A merangsang anak ginjal untuk melepaskan hormon adrenalin dan memacu jantung lebih cepat dan kuat, sehingga tekanan darah akan meningkat. Jika hal ini terus terjadi akan menyebabkan hipertensi maupun komplikasi penyakit kronis lain. Sedangkan untuk kepribadian tipe B memiliki kemungkinan lebih kecil untuk mengalami penyakit kronis. Hal ini disebabkan pasien dengan kepribadian tipe B memiliki sifat-sifat yang cenderung tidak meningkatkan hormon adrenalin pada pasien. Jika individu dengan kepribadian tipe B mengalami stres, akan berpengaruh pada kecemasan individu yang berujung pada terjadinya gangguan lambung seperti gastrointestinal (hipersekresi asam lambung) dan lain-lain (Niven, 2002; Robbins, 2006; Pinel, 2009; Davison, Neale, Kring, 2010).

Dari hal-hal yang telah disebutkan diatas dapat dikatakan bahwa, adanya perubahan gaya hidup masyarakat cenderung menekankan pada aktivitas praktis. Hal ini berdampak pada pengurangan aktivitas fisik yang sehat, yang terkait erat dengan munculnya berbagai penyakit kronis di masyarakat. Penyakit kronis mengharuskan pasien untuk rutin mengonsumsi obat sesuai dengan aturan yang telah di tetapkan oleh petugas kesehatan. Salah satu faktor yang dapat mempengaruhi memunculkan penyakit kronis dan kepatuhan pasien dalam mengonsumsi obat adalah kepribadian yang terbagi menjadi dua yaitu kepribadian tipe A dan tipe B, sehingga peneliti tertarik melihat bagaimana perbedaan kepatuhan mengonsumsi obat pada pasien penyakit kronis di Denpasar ditinjau dari kepribadian tipe A dan kepribadian tipe B. Dalam penelitian ini lebih menekankan pada penyakit hipertensi.

Berdasarkan pertimbangan diatas maka peneliti ingin mengetahui apakah ada perbedaan kepatuhan mengonsumsi obat antara tipe kepribadian A dan tipe kepribadian B pada pasien hipertensi di Kota Denpasar. Penelitian ini diharapkan dapat memberikan sumbangan pengetahuan dan penambahan wawasan pada psikologi kesehatan dan psikologi klinis yang terkait dengan kepatuhan pasien dalam mengonsumsi obat. Manfaat praktis dari penelitian ini yaitu dapat sebagai masukan dan pertimbangan dalam membuat kebijakankebijakan di tempat pelayanan kesehatan di Kota Denpasar pada umumnya, dan RSUP Sanglah Denpasar pada khususnya. Oleh karena itu pelayanan kesehatan dapat membuat kebijakan untuk pelayanan pasien dengan menyesuaikan pelayanan sesuai kepribadian pasien. Sedangkan untuk pasien hipertensi, penelitian ini diharapkan dapat menjadi tambahan 
pengetahuan pada pasien hipertensi agar dapat mengetahui dan memahami tipe kepribadian diri masing-masing sehingga mampu mengontrol perilaku dalam mematuhi aturan mengonsumsi obat.

\section{METODE}

\section{Hipotesis}

Hipotesis penelitian merupakan jawaban atau dugaan sementara terhadap rumusan masalah penelitian yang harus diuji kebenarannya (Sugiyono, 2012; Siregar, 2013). Berdasarkan hal tersebut, maka hipotesis dalam penelitian ini adalah hipotesis nol (Ho) tidak ada perbedaan kepatuhan mengonsumsi obat pada pasien hipertensi yang memiliki kepribadian tipe A dan tipe B di Denpasar. Sedangkan, hipotesis alternatif (Ha) ada perbedaan kepatuhan mengonsumsi obat pada pasien hipertensi yang memiliki kepribadian tipe A dan tipe B di Denpasar.

\section{Variabel dan definisi operasional}

Variabel penelitian adalah segala sesuatu yang berbentuk apa saja yang ditretapkan oleh peneliti untuk dipelajari sehingga diperoleh informasi mengenai hal tersebut, kemudian dapat ditarik kesimpulan mengenai hal yang diteliti. Penelitian ini menggunakan dua variabel yaitu variabel bebas dan variabel tergantung. Variabel bebas merupakan variabel yang menjadi penyebab timbulnya perubahan pada variabel tergantung. Selanjutnya, variabel tergantung merupakan variabel yang dipengaruhi atau yang menjadi akibat, karena adanya perlakuan pada variabel bebas (Sugiyono, 2012). Variabel bebas dalam penelitian ini adalah kepribadian yang terdiri menjadi dua dimensi yaitu kepribadian tipe A dan kepribadian tipe $\mathrm{B}$, sedangkan variabel tergantung dalam penelitian ini adalah kepatuhan mengonsumsi obat.

Definisi operasional dari kepribadian adalah cara individu agar dapat secara total bereaksi, berinteraksi atau menyesuaikan diri terhadap lingkungan. Kepribadian dibagi menjadi dua dimensi yaitu kepribadian tipe A dan kepribadian tipe B. Kepribadian tipe A memiliki karakteristik terburuburu, memiliki jiwa pesaing kuat, perfeksionis, dan polyphasic, sedangkan kepribadian tipe B memiliki karakteristik santai, memiliki jiwa pesaing yang rendah, monophasic, dan tidak perfeksionis.

Selanjutnya, definisi operasional dari kepatuhan mengonsumsi obat perilaku positif pasien dalam menaati anjuran tenaga medis untuk mengonsumsi obat sesuai aturan yang telah ditetapkan. Aspek-aspek yang mencakup kepatuhan pasien dalam mengonsumsi obat yaitu : (1) frekuensi kelupaan pasien dalam mengonsumsi obat; (2) kesengajaan pasien hipertensi berhenti mengonsumsi obat tanpa diketahui oleh tim medis; (3) kemampuan mengontrol diri untuk tetap mengonsumsi obat. Kepribadian pasien dan kepatuhan mengonsumsi obat nantinya akan diukur menggunakan skala yang terdiri dari 48 aitem pada skala kepribadian dan 50 aitem pada skala kepatuhan mengonsumsi obat. Aitem-aitem pernyataan yang dibuat menggunakan Skala Likert.

\section{Responden}

Populasi pada penelitian ini adalah pasien hipertensi di Kota Denpasar, sedangkan sampel yang digunakan dalam penelitian ini adalah pasien hipertensi yang sedang menjalani rawat jalan di RSUP Sanglah Denpasar saat penelitian berlangsung dengan kriteria sampel yang digunakan yaitu: (1) mengonsumsi obat hipertensi satu tablet atau kapsul dalam sehari; (2) usia sampel dalam penelitian ini antara 45 tahun sampai dengan 59 tahun (middle age); (3) terdiagnosis hipertensi selama satu tahun hingga sepuluh tahun; (4) pasien yang sedang menjalani rawat jalan di RSUP Sanglah dan berdomisili di Denpasar.

Metode pengambilan sample yang digunakan adalah nonprobabilitas sampling yaitu setiap unit dalam populasi yang telah ditentukan tidak memiliki kesempatan yang sama untuk menjadi sampel penelitian. Teknik nonprobabilitas sampling yang digunakan adalah purposive sampling yaitu teknik pengambilan sampel yang dilakukan berdasarkan pada kriteria-kriteria tertentu (Siregar, 2013).

\section{Tempat Penelitian}

Penelitian ini mengambil tempat di lima bagian pelayanan RSUP Sanglah Denpasar yaitu Bagian Poliklinik Umum Penyakit Dalam, Bagian Poliklinik Umum Jantung, Bagian Poliklinik Penyakit Dalam Wings Internasional, Bagian Poliklinik Jantung Wings Internasional; dan Triage Medic IGD (Instalasi Gawat Darurat) RSUP Sanglah Denpasar.

\section{Prosedur pengambilan data}

Penelitian ini merupakan penelitian kuantitatif dengan metode komparatif. Metode komparatif atau metode perbedaan merupakan suatu metode yang digunakan untuk mengetahui perbedaan antara dua variabel (data) atau lebih (Siregar, 2013). Metode komparatif digunakan dalam penelitian ini karena penelitian ini membedakan kepatuhan mengonsumsi obat pasien hipertensi di Denpasar yang memiliki kepribadian tipe A dan kepribadian tipe B.

Adapun langkah-langkah yang dilakukan peneliti dalam menjalankan penelitian ini adalah sebagai berikut.

1. Peneliti menentukan bagian-bagian di RSUP Sanglah Denpasar untuk proses penelitian. Adapun bagian yang digunakan dalam proses penelitian yaitu: (a) Bagian Poliklinik Umum Penyakit Dalam; (b) Bagian Poliklinik Umum Jantung; (c) Bagian Poliklinik Penyakit Dalam Wings Internasional; (d) Bagian Poliklinik Jantung Wings 
Internasional; (e) Triage Medic IGD (Instalasi Gawat Darurat) RSUP Sanglah Denpasar.

2. Peneliti meminta bantuan pada para petugas atau perawat yang telah ditentukan oleh kepala ruangan untuk membantu pengambilan sampel saat penelitian berlangsung.

3. Setelah menemui para petugas yang akan membantu peneliti dalam pengambilan sampel, peneliti memberikan informasi dan pemahaman tentang penelitian yang akan dilakukan kepada petugas yang telah ditetapkan. Pemberian informasi dan pemahaman kepada para petugas menekankan pada tata cara pengisian skala dan karakteristik subjek penelitian.

4. Setelah peneliti memberikan informasi dan pemahaman penelitian, peneliti melakukan simulasi yang langsung melibatkan petugas yang akan membantu dalam pengisian skala.

5. Pada saat proses penelitian berlangsung, peneliti ikut serta dalam proses pengambilan sampel sekaligus melakukan monitoring dan evaluasi di tempat-tempat proses penelitian berlangsung.

6. Waktu penelitian dilakukan bersamaan di semua tempat yang telah ditentukan pada saat waktu kerja yaitu pukul 09.00 WITA hingga 13.00 WITA. Di luar jam kerja seperti pada tanggal 5 Mei 2013, penelitian dilakukan hanya di bagian Poliklinik Penyakit Dalam Wings Internasional, Poliklinik Jantung Wings Internasional, dan Triage Medic IGD (Instalasi Gawat Darurat) RSUP Sanglah Denpasar.

Peneliti menyebarkan sebanyak 270 skala kepada 270 subjek. Semua skala kembali kepada peneliti sesuai dengan jumlah yang disebarkan, tetapi tiga skala tidak dapat dianalisis karena tidak diisi penuh oleh sampel penelitian. Oleh karena itu, skala yang dapat dianalisis berjumlah 267 skala.

\section{Teknik Analisis Data}

Validitas suatu tes atau instrumen pengukuran dapat dikatakan mempunyai validitas yang tinggi apabila alat tersebut menjalankan fungsi ukurnya, atau memberikan hasil ukur yang sesuai dengan maksud yang dilakukannya pengukuran tersebut. Validitas aitem-aitem pada skala penelitian ini dilihat menggunakan korelasi aitem dengan skor total skala. Aitem-aitem dalam penelitian ini dapat dikatakan valid jika memiliki korelasi aitem skor total $\geq 0,3$. Korelasi aitem dalam penelitian ini dihitung dengan menggunakan program SPSS versi 17 (Azwar, 2010).

Reliabilitas merupakan penerjemahan dari kata reliability yang mempunyai asal kata rely dan ability. Pengukuran yang memiliki reliabilitas tinggi disebut sebagai pengukuran yang reliabel. Jadi reliabilitas adalah sejauh mana hasil pengukuran dapat dipercaya. Hasil pengukuran dapat dipercaya hanya apabila dalam beberapa kali pelaksanaan pengukuran terhadap kelompok subjek yang sama diperoleh hasil yang relatif sama, selama aspek yang diukur dalam diri subjek memang belum berubah. Uji reliabilitas dalam penelitian ini menggunakan Koefisien Alpha Cronbach (dalam Azwar, 2010). Koefisien Alpha Cronbach digunakan untuk meyakinkan bahwa belahan-belahan tes yang diperoleh dapat memenuhi asumsi paralel. Aitem-aitem dalam penelitian ini dikatakan memiliki reliabilitas tinggi jika memiliki koefisien $>0,60$ (Azwar, 2010).

Analisis data pada penelitian ini menggunakan metode analisis parametrik dengan independent sample t test. Independent sample t tes digunakan pada kelompok-kelompok sampel penelitian yang dapat dipisahkan secara tegas. Artinya anggota kelompok A tidak ada yang menjadi anggota kelompok B (Siregar, 2013). Sebelum melakukan uji analisis data, terdapat dua syarat yang harus dipenuhi, yaitu: uji homogenitas dan uji normalitas. Uji normalitas, uji homogenitas maupun analisis data yang dilakukan menggunakan program SPSS versi 17. Uji normalitas adalah uji yang dilakukan untuk melihat apakah data memiliki distribusi normal atau tidak, sehingga dapat dugunakan dalam statistik parametrik (statistik inferensial). Uji normalitas digunakan untuk menguji apakah variabel tergantung, variabel bebas, atau keduanya mempunyai distribusi normal atau tidak. Pada penelitian ini uji normalitas menggunakan rumus Kolmogorov-Smirnov menggunakan program SPSS versi 17. Data dikatakan berdistribusi normal apabila nilai $\mathrm{p}>0,05$ (Sugiyono, 2012). Uji homogenitas digunakan untuk mengetahui apakah varians skor yg diukur pada kedua sampel memiliki varians yang sama atau tidak. Uji homogenitas menggunakan uji levene test, dengan tingkat signifikan $>0.05$ yang berarti data bersifat homogen, sedangkan jika tingkat signifikan $<0.05$ data bersifat tidak homogen (Siregar, 2013).

\section{HASIL PENELITIAN}

Pengambilan data dalam uji coba penelitian ini dilakukan dengan menyebarkan kuesioner ke lima bagian pelayanan hipertensi yang terdapat di RSUP Sanglah Denpasar. Penelitian dilakukan selama lima hari yaitu pada 3 Mei 2013 sampai dengan tanggal 7 Mei 2013, pukul 09.0013.00 WITA. Uji coba alat ukur secara langsung atau yang disebut dengan try out terpakai. Try out terpakai dilakukan oleh peneliti karena waktu yang diperlukan tidak memungkinkan peneliti untuk mengambil data dua kali. Data yang digunakan untuk uji coba alat ukur adalah data yang berasal dari kuesioner hari pertama. Subjek dalam penelitian ini adalah pasien hipertensi yang sedang menjalani rawat jalan di RSUP Sanglah Denpasar saat penelitian berlangsung. Uji coba penelitian ini dilakukan dengan menyebarkan kuesioner kepada 270 orang responden. Namun hanya 267 kuesioner yang dapat dianalisis, mengingat tiga kuesioner tidak diisi lengkap oleh subjek. Data tersebut kemudian dianalisis untuk mengetahui validitas dan reliabilitasnya. 
Pengambilan data dilaksanakan dengan menyebarkan kuesioner dengan dua skala yaitu, skala kepribadian tipe A dan tipe B yang terdiri dari 48 aitem dan skala kepatuhan mengonsumsi obat yang terdiri dari 50 aitem. Melalui uji kesahihan aitem yang dilakukan pada skala kepribadian tipe A dan tipe B diperoleh koefisien korelasi yang bergerak dari 0,569 hingga 0,423 . Terdapat 16 aitem yang gugur dari 48 aitem yang diuji, sehingga jumlah aitem yang sahih pada Skala Kepribadian berjumlah 32 aitem. Selanjutnya hasil uji kesahihan aitem pada skala kepatuhan mengonsumsi obat, diperoleh koefisien korelasi yang bergerak dari -0,057 hingga 0,471 . Terdapat 11 aitem yang gugur dari 50 aitem yang diuji, sehingga untuk jumlah aitem yang sahih pada Skala Kepatuhan Mengonsumsi Obat berjumlah 39 aitem.

Uji reliabilitas dalam penelitian ini menggunakan Koefisien Alpha Cronbach (dalam Azwar, 2010). Skala kepribadian pada penelitian ini memiliki nilai alpha $(\alpha) 0,645$ . Nilai Alpha $(\alpha)$ sebesar 0,645 ini menunjukkan bahwa skala ini mampu mencerminkan 64,50\% variasi yang terjadi pada skor murni sampel yang bersangkutan sehingga dapat digunakan untuk mengukur Kepribadian. Selanjutnya skala kepatuhan mengonsusmi obat pada penelitian ini memiliki nilai Alpha $(\alpha) 0,868$. Nilai Alpha $(\alpha)$ sebesar 0,868 ini menunjukkan bahwa skala ini mampu mencerminkan 86,80\% variasi yang terjadi pada skor murni sampel yang bersangkutan sehingga dapat digunakan untuk mengukur kepatuhan mengonsumsi obat.

Sebelum melakukan uji analisis data, maka dilakukan uji normalitas untuk mengetahui distribusi atau persebaran data penelitian apakah normal atau tidak. Berdasarkan dari hasil uji normalitas variabel kepribadian diperoleh nilai (p) sebesar 0,065 yang artinya nilai probalilitas di atas 0,05 (p > $0,05)$. Hal ini menunjukkan bahwa sebaran data pada variabel kepribadian bersifat normal. Sedangkan sebaran data pada variabel kepatuhan mengonsumsi obat memiliki nilai signifikansi dengan probabilitas (p) 0,199 yang artinya probalilitas di atas $0,05(\mathrm{p}>0,05)$ sehingga hal ini menunjukkan bahwa sebaran data pada variabel kepatuhan mengonsumsi obat bersifat normal.

Selanjutnya dilakukan uji homogenitas pada data untuk mengetahui varian skor sebuah variabel yang diukur pada setiap kelompok yang diuji relatif homogen atau tidak. Dari hasil uji homogenitas, diketahui bahwa varians pada setiap kelompok penelitian memiliki nilai signifikansi dengan probabilitas (p) 0,061 atau memiliki probabilitas di atas 0,05 atau $\mathrm{p}>0,05$. Hal ini menunjukkan bahwa varians skor variabel yang diukur pada setiap kelompok yang diuji dalam penelitian ini adalah bersifat homogen.

Setelah kedua syarat untuk melakukan analisis data telah dipenuhi, dilanjutkan dengan menggunakan metode analisis independent samples $t$ test dengan alat bantu perangkat lunak SPSS 17.0.
Tabel. 2. Hasil Uji T

\begin{tabular}{c|c}
\hline Keterangan & Nilai \\
\hline Uji Homogenitas & \\
Levene's Test & \\
Nilai F & 3.531 \\
Nilai Sig. & 0.061 \\
\hline Uji T & \\
Nilai Sig. (2-tailed) & 0.001 \\
\hline
\end{tabular}

Berdasarkan atas pedoman dalam menolak atau menerima hipotesis jika nilai $\mathrm{p}$ yang diberoleh lebih kecil dari $0,05(\mathrm{p}<0,05)$ maka hipotesis nol $\left(\mathrm{H}_{0}\right)$ yang telah ditetapkan ditolak, sehingga hipotesis alternatif (Ha) yang ditetapkan akan diterima. Hasil uji hipotesis penelitian diperoleh nilai $\mathrm{p}$ sebesar $0,001(\mathrm{p}<0,05)$ maka hipotesis nol yang ada ditolak dan hipotesis alternatif yang ada diterima. Jadi hipotesis yang diterima berbunyi "Ada perbedaan kepatuhan mengonsumsi obat pada pasien hipertensi yang memiliki kepribadian tipe A dan tipe B di Denpasar".

Tabel. 3. Kategori Skor Kepatuhan Mengonsumsi Obat

\begin{tabular}{|c|c|c|c|}
\hline Kepribadian & Kategori & Jumlah & Presentase (\%) \\
\hline \multirow[t]{2}{*}{ Tipe A } & Baik & 26 & $19,26 \%$ \\
\hline & Buruk & 109 & $80,74 \%$ \\
\hline \multicolumn{2}{|c|}{ Total } & 135 & $100 \%$ \\
\hline \multirow[t]{2}{*}{ Tipe B } & Baik & 52 & $39,39 \%$ \\
\hline & Buruk & 80 & $60,61 \%$ \\
\hline \multicolumn{2}{|c|}{ Total } & 132 & $100 \%$ \\
\hline
\end{tabular}

Berdasarkan tabel diatas, dapat dilihat bahwa subjek dengan kepribadian tipe A yang memiliki kepatuhan mengonsumsi obat baik berjumlah 26 subjek atau 19,26\% sedangkan subjek dengan kepribadian tipe A yang memiliki kepatuhan mengonsumsi obat buruk berjumlah 109 subjek atau $80,74 \%$. Selanjutnya subjek dengan kepribadian tipe B yang memiliki kepatuhan mengonsumsi obat baik sebanyak 52 subjek atau $39,39 \%$ sedangkan subjek berkepribadian tipe B yang memiliki kepatuhan mengonsumsi obat buruk berjumlah 80 subjek atau sebesar $60,61 \%$.

Berdasarkan total subjek sejumlah 267, lebih banyak subjek yang memiliki kepatuhan mengonsumsi obat yang buruk yaitu 189 subjek, yang terdiri dari 109 subjek dengan kepribadian tipe A dan 80 subjek dengan kepribadian tipe B. Pasien yang memiliki kepatuhan yang baik dalam mengonsumsi obat berjumlah 78 subjek, yang terdiri dari 26 subjek dengan kepribadian tipe A dan 52 subjek dengan kepribadian tipe B. Berdasarkan hasil kategorisasi dapat dikatakan bahwa baik pasien dengan kepribadian tipe A maupun tipe B lebih banyak yang tidak mematuhi proses pengobatan, walaupun pada kategori kepatuhan mengonsumsi obat yang baik lebih didominasi oleh pasien dengan kepribadian tipe $\mathrm{B}$, tetapi dari total keseluruhan pasien dengan kepribadian tipe B lebih banyak yang tidak patuh dalam mengonsumsi obat. 
Tabel. 4. Kategori Skor Kepatuhan Mengonsumsi Obat berdasarkan Kepribadian Tipe A dan Jenis Kelamin

\begin{tabular}{|c|c|c|c|}
\hline Jenis Kelamin & Kategori & Jumlah & Presentase (\%) \\
\hline \multirow[b]{2}{*}{ Laki-laki } & Baik & 12 & $8,89 \%$ \\
\hline & Buruk & 68 & $50,37 \%$ \\
\hline \multicolumn{2}{|c|}{ Total } & 80 & $59,26 \%$ \\
\hline \multirow[b]{2}{*}{ Perempuan } & Baik & 14 & $10,37 \%$ \\
\hline & Buruk & 41 & $30,37 \%$ \\
\hline \multicolumn{2}{|c|}{ Total } & 55 & $40,74 \%$ \\
\hline
\end{tabular}

Berdasarkan tabel diatas dapat dikatakan bahwa subjek berjenis kelamin laki-laki dengan kepribadian tipe A memiliki jumlah skor kepatuhan mengonsumsi obat yang baik sebanyak 12 subjek atau 8,89\% dan skor kepatuhan mengonsumsi obat yang buruk sebanyak 68 subjek atau $50,37 \%$ sehingga dapat dikatakan bahwa subjek berjenis kelamin laki-laki dengan kepribadian tipe A lebih banyak yang tidak patuh dalam mengonsumsi obat dibandingkan dengan subjek laki-laki dengan kepribadian tipe A yang patuh dalam mengonsumsi obat.

Selanjutnya subjek berjenis kelamin perempuan dengan kepribadian tipe A memiliki jumlah skor kepatuhan mengonsumsi obat yang baik sebanyak 14 subjek atau 10,37\% dan skor kepatuhan mengonsumsi obat yang buruk sebanyak 41 subjek atau 30,37\% sehingga dapat dikatakan bahwa subjek berjenis kelamin perempuan dengan kepribadian tipe A lebih banyak yang tidak mematuhi proses dalam mengonsumsi obat. Berdasarkan jenis kelamin subjek ditinjau dari kepribadian tipe A, subjek laki-laki lebih banyak yang tidak mematuhi proses pengobatan yaitu 68 subjek atau 50,37\% dibandingkan dengan subjek perempuan yaitu 41 subjek atau 30,37\%.

Tabel. 5. Kategori Skor Kepatuhan Mengonsumsi Obat berdasarkan Kepribadian Tipe B dan Jenis Kelamin

\begin{tabular}{|c|c|c|c|}
\hline Jenis Kelamin & Kategori & Jumlah & Presentase (\%) \\
\hline \multirow[b]{2}{*}{ Laki-laki } & Baik & 21 & $15,91 \%$ \\
\hline & Buruk & 53 & $40,15 \%$ \\
\hline \multicolumn{2}{|c|}{ Total } & 74 & $56,06 \%$ \\
\hline \multirow[b]{2}{*}{ Perempuan } & Baik & 31 & $23,49 \%$ \\
\hline & Buruk & 27 & $20,45 \%$ \\
\hline \multicolumn{2}{|c|}{ Total } & 58 & $43,94 \%$ \\
\hline
\end{tabular}

Berdasarkan tabel diatas dapat dikatakan bahwa subjek berjenis kelamin laki-laki dengan kepribadian tipe B memiliki jumlah skor kepatuhan mengonsumsi obat yang baik sebanyak 21 subjek atau $15,91 \%$ dan skor kepatuhan mengonsumsi obat yang buruk sebanyak 53 subjek atau $40,15 \%$ sehingga dapat dikatakan bahwa subjek berjenis kelamin laki-laki dengan kepribadian tipe B lebih banyak yang tidak patuh dalam mengonsumsi obat dibandingkan dengan subjek yang patuh dalam mengonsumsi obat.

Selanjutnya subjek berjenis kelamin perempuan dengan kepribadian tipe B memiliki jumlah skor kepatuhan mengonsumsi obat yang baik sebanyak 31 subjek atau 23,49\% dan skor kepatuhan mengonsumsi obat yang buruk sebanyak 27 subjek atau 20,45\% sehingga dapat dikatakan bahwa subjek berjenis kelamin perempuan dengan kepribadian tipe B lebih banyak yang patuh dalam mengonsumsi obat. Berdasarkan jenis kelamin subjek ditinjau dari kepribadian tipe B, subjek laki-laki lebih banyak yang tidak mematuhi proses pengobatan yaitu 53 subjek atau 40,15\% dibandingkan dengan subjek perempuan yaitu 27 subjek atau 20,45.

Tabel. 6. Kategorisasi Skor Kepatuhan Mengonsumsi Obat berdasarkan Usia Pasien Hipertensi

\begin{tabular}{c|c|c|c}
\hline Usia (Tahun) & Kategori & Jumlah & Presentase (\%) \\
\hline \multirow{2}{*}{45 hingga 51 } & Baik & 38 & $29,46 \%$ \\
\cline { 2 - 4 } & Buruk & 91 & $70,54 \%$ \\
\hline \multicolumn{2}{|c|}{ Total } & $\mathbf{1 2 9}$ & $\mathbf{1 0 0 \%}$ \\
\hline \multirow{2}{*}{52 hingga 59 } & Baik & 40 & $28,99 \%$ \\
\cline { 2 - 4 } & Buruk & 98 & $71,01 \%$ \\
\hline \multicolumn{2}{|c|}{ Total } & $\mathbf{1 3 8}$ & $\mathbf{1 0 0 \%}$ \\
\hline
\end{tabular}

Berdasarkan tabel diatas dapat dikatakan bahwa dari 267 subjek sebanyak 129 subjek berusia antara 45 tahun hingga 51 tahun dengan subjek yang memiliki kepatuhan baik dalam mengonsumsi obat sebanyak 38 subjek atau 29,46\%, sedangkan subjekn yang memiliki kepatuhan mengonsumsi obat buruk sebanyak 91 subjek atau 70,54\%. Selanjutnya subjek yang berusia antara 52 tahun hingga 59 tahun yang memiliki kepatuhan mengonsumsi obat baik sebanyak 40 subjek atau 28,99\% dan subjek dengan kepatuhan mengonsumsi obat yang buruk sebanyak 98 subjek atau $71,01 \%$.

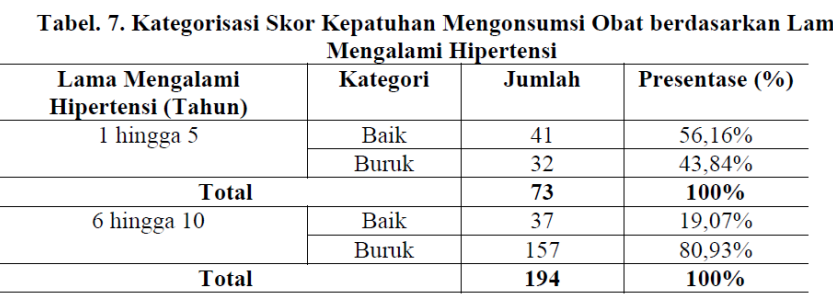

Berdasarkan tabel diatas dapat dijelaskan bahwa subjek yang telah mengalami hipertensi antara satu hingga lima tahun yang memiliki kepatuhan mengonsumsi obat baik sebanyak 41 subjek atau 56,16\% dan subjek yang memiliki kepatuhan mengonsumsi obat buruk sebesar 32 subjek atau $43,84 \%$. Selanjutnya subjek yang telah mengalami hipertensi selama enam hingga sepuluh tahun yang memiliki kepatuhan mengonsumsi obat baik sebanyak 37 subjek atau 19,07\% dan subjek yang memiliki kepatuhan mengonsumsi obat buruk sebesar 157 subjek atau $80,93 \%$.

\section{PEMBAHASAN DAN KESIMPULAN}

Berdasarkan hasil analisis perbandingan dengan menggunakan independent samples $t$ test, didapat bahwa nilai signifikansi $\mathrm{p}$ adalah sebesar 0,001 ( $\mathrm{p}<0,05)$. Hal ini menunjukkan bahwa terdapat perbedaan kepatuhan mengonsumsi obat secara signifikan antara kepribadian tipe A dengan kepribadian tipe B pada pasien hipertensi di Denpasar, atau dapat disimpulkan bahwa hipotesis nol (Ho) dapat ditolak dan hipotesis alternatif (Ha) yang diajukan dalam penelitian ini diterima.

Berdasarkan hasil kategorisasi skor Skala Kepribadian, menunjukkan bahwa kelompok kepribadian tipe A sejumlah 135 subjek dan kepribadian tipe B sejumlah 132 subjek. Dari 
jumlah total subjek yang memiliki skor kepatuhan mengonsumsi obat yang buruk lebih banyak terdapat pada kelompok kepribadian tipe A yaitu 109 dan kelompok subjek berkepribadian tipe B berjumlah 80 subjek. Subjek yang memiliki skor kepatuhan mengonsumsi obat yang baik dengan kepribadian tipe A berjumlah 26 subjek dan subjek dengan kepribadian tipe B berjumlah 52 subjek, sehingga dapat dikatakan subjek yang memiliki skor kepatuhan mengonsumsi obat yang buruk lebih mendominasi baik pada kelompok subjek dengan kepribadian tipe A maupun kelompok subjek dengan kepribadian tipe B.

Hal ini sesuai dengan pernyataan bahwa individu dengan kepribadian tipe A yang memiliki karakteristik terburu-buru, jiwa pesaing kuat, perfeksionis dan polyphasic memiliki kecenderungan untuk mengalami penyakit kronis dan stres yang lebih tinggi dibandingkan individu dengan kepribadian tipe B yang memiliki karakteristik santai, jiwa pesaing rendah, monophasic, dan tidak perfeksionis. Hal ini dikarenakan karakteristik individu dengan kepribadian tipe A cenderung memacu anak ginjal melepaskan hormon adrenalin, sehingga terdapat peningkatan hormon adrenalin yang menyebabkan detak jantung meningkat dan dapat meningkatkan tekanan darah. Jika hal ini terjadi secara berkesinambungan, dapat berakibat timbulnya penyakit hipertensi. Oleh karena itu, individu dengan kepribadian tipe A memiliki kecenderungan lebih besar mengalami hipertensi dibandingkan dengan individu dengan kepribadian tipe B (Pinel, 2009; Davison, Neale, Kring, 2010).

Selanjutnya dijelaskan bahwa individu dengan kepribadian tipe A dikatakan memiliki kecenderungan untuk mengalami stres yang lebih besar dibandingkan dengan individu dengan kepribadian tipe B. Jika individu mengalami stres, individu cenderung memunculkan perilaku maladaptif. Salah satu dari perilaku maladaptif yang dimunculkan individu pada proses pengobatan jangka panjang atau pada proses pengobatan penyakit kronis adalah ketidakpatuhan mengonsumsi obat yang telah dianjurkan (Handaya, 2009; Haryati, 2010). Hal serupa dinyatakan oleh Niven (2002) bahwa individu yang cenderung tidak patuh dalam proses pengobatan adalah individu yang memiliki kepribadian dengan karakteristik mudah stres dan pada kehidupan sosial lebih memusatkan pada diri sendiri.

Berdasarkan hasil kategoriasi skor kepatuhan mengonsumsi obat dengan jenis kelamin pasien, jumalah pasien laki-laki lebih banyak dibandingkan dengan subjek perepuan yaitu, 154 subjek laki-laki dan 113 subjek perempuan. Sebanyak 121 subjek laki-laki memiliki kepatuhan mengonsumsi obat yang buruk dengan kepribadian tipe A berjumlah 68 subjek dan 53 subjek dengan kepribadian tipe B, sedangkan subjek laki-laki yang patuh dalam megonsumsi obat sebanyak 33 subjek yang terdiri dari 12 subjek dengan kepribadian tipe A dan 21 subjek dengan kepribadian tipe B. Selanjutnya subjek perempuan yang memiliki kepatuhan baik dalam mengonsumsi obat berjumlah 45 subjek, dengan subjek berkepribadian tipe A berjumlah 14 subjek dan subjek dengan kepribadian tipe B berjumlah 31 subjek. Subjek perempuan yang memiliki skor buruk dalam kepatuhan mengonsumsi obat berjumlah 68 subjek yang terdiri dari 41 subjek dengan kepribadian tipe A dan 27 subjek dengan kepribadian tipe B. Oleh karena itu dapat dikatakan bahwa baik subjek dengan jenis kelamin laki-laki maupun perempuan lebih banyak yang tidak patuh dalam mengonsumsi obat. Walaupun jumlah subjek laki-laki lebih banyak yang tidak mematuhi proses pengobatan.

Hal ini dapat diperkuat dari teori perkembangan dewasa madya yang dikemukakan Santrock (2002) dan Jaya (2009) bahwa laki-laki pada usia dewasa madya atau middle age jauh lebih berisiko memiliki penyakit kronis. Laki-laki pada usia dewasa madya memiliki tugas seperti tanggung jawab terhadap keluarga, pekerjaan yang cenderung monoton, dan lingkungan sosial yang mengakibatkan timbulnya stres pada laki-laki. Selain itu, faktor gaya hidup laki-laki usia dewasa madya yang cenderung kurang mempedulikan kesehatan seperti merokok, mengonsumsi alkohol dan makanan tinggi lemak dapat meningkatkan resiko mengalami penyakit kronis.

Selanjutnya usia dewasa madya pada perempuan, merupakan saat dimana perempuan mulai kembali masuk ke dunia pekerjaan, yaitu setelah perempuan dapat bebas dari tanggung jawab sebagai ibu rumah tangga atau mengurus anak. Saat memasuki masa inilah perempuan lebih memiliki kepuasan hidup dibandingkan dengan perempuan yang tidak bekerja, sehingga perempuan usia dewasa madya yang bekerja memiliki tingkat stres lebih rendah dibandingkan dengan perempuan yang tidak berkerja. Namun, pada perempuan yang memasuki usia dewasa akhir yaitu 60 tahun keatas atau yang sudah memasuki masa menopause karena adanya perubahan hormon pada perempuan. Berbeda dengan laki-laki yang telah mulai memasuki masa bekerja pada usia dewasa awal dan cenderung mendapatkan pekerjaan yang monoton sampai masa pensiun tiba, yang dapat membuat tingkat stres lebih tinggi dibandingkan dengan perempuan. Dengan demikian, laki-laki usia dewasa madya dianggap memiliki risiko lebih tinggi mengalami penyakit kronis dibandingkan dengan perempuan usia dewasa madya.

Selanjutnya berdasarkan kategori skor kepatuhan mengonsumsi obat berdasarkan usia pasien hipertensi dapat dikatakan bahwa baik subjek yang berusia 45 tahun hingga 51 tahun maupun 52 tahun hingga 59 tahun lebih banyak yang tidak mematuhi proses dalam mengonsumsi obat, yaitu 91 subjek atau 70,54\% dan 98 subjek atau 71,09\%, sedangkan subjek usia 45 tahun hingga 51 tahun yang mematuhi proses dalam mengonsumsi obat berjumlah 38 subjek atau 29,46\% dan subjek yang berusia 52 tahun hingga 59 tahun yang 
memiliki kepatuhan baik dalam mengonsumsi obat berjumlah 40 subjek atau $29,46 \%$.

Hasil kategorisasi ini berbeda dengan pernyataan Jaya (2009) dan Ramadona (2011) yang menyatakan bahwa dari segi faktor usia, pasien hipertensi yang berusia 45 tahun hingga 59 tahun cenderung lebih patuh dalam mengonsumsi obat, karena pada usia 45 tahun hingga 59 tahun merupakan usia awal individu mengalami penyakit kronis sehingga rasa ingin tahu dan sembuh lebih besar. Sedangkan hasil kategorisasi dalam penelitian ini pasien hipertensi usia 45 hingga 59 tahun lebih banyak yang tidak mematuhi proses pengobatan yaitu 189 subjek.

Hasil kategorisasi kepatuhan mengonsumsi obat berdasarkan lama mengalami hipertensi memperoleh hasil pasien yang telah mengalami hipertensi selama satu hingga lima tahun yang memiliki kepatuhan mengonsumsi obat baik sebanyak 41 subjek atau 56,16\% sedangkan pasien yang telah mengalami hipertensi selama enam tahun hingga sepuluh tahun yang memiliki kepatuhan mengonsumsi obat baik sebanyak 37 subjek atau 19,07\%. Selanjutnya subjek yang telah mengalami hipertensi selama satu tahun hingga lima tahun yang memiliki kepatuhan mengonsumsi obat buruk berjumlah 32 subjek atau 43,84\% dan subjek yang telah mengalami hipertensi selama enam tahun hingga sepuluh tahun dengan kepatuhan mengonsumsi obat buruk berjumlah 157 subjek atau $80,93 \%$.

Hasil kategori kepatuhan mengonsumsi obat berdasarkan lama mengalami hipertensi senada dengan pernyataan Ramadona (2011) bahwa pasien yang telah mengalami hipertensi selama satu hingga lima tahun cenderung lebih mamatuhi proses dalam mengonsumsi obat karena adanya rasa ingin tahu yang besar dan keinginan untuk sembuh besar, sedangkan pasien yang telah mengalami hipertensi enam hingga sepuluh tahun memiliki kecenderungan memiliki kepatuhan mengonsumsi obat yang lebih buruk. Hal ini dikarenakan pengalaman pasien yang lebih banyak, dimana pasien yang telah mematuhi proses pengobatan tetapi hasil yang didapatkan tidak memuaskan, sehingga pasien cenderung pasrah dan tidak mematuhi proses pengobatan yang dijalani.

Berdasarkan hasil analisis kepatuhan mengonsumsi obat berdasarkan kepribadian, jenis kelamin, usia subjek, dan lama mengalami hipertensi dapat disimpulkan hasil penelitian yang menyatakan bahwa jumlah subjek yang memiliki kepatuhan mengonsumsi obat buruk lebih banyak dibandingkan dengan subjek yang memiliki kepatuhan mengonsumsi obat baik. Hal ini dikarenakan adanya faktorfaktor lain yang mungkin dapat mempengaruhi seperti jenis kelamin dan lama mengalami hipertensi. Dalam penelitian ini tidak terlihat adanya perbedaan kepatuhan mengonsumsi obat pasien berdasarkan faktor usia, baik pasien yang berusia 45 tahun hingga 51 tahun maupun pasien yang berusia 52 tahun hingga 59 tahun. Selain itu terdapat keterbatasan dalam penelitian ini, dimana penelitian ini tidak melihat faktor tingkat pendidikan, hubungan antara pasien dengan petugas kesehatan maupun keluarga, sikap maupun emosi pasien. Diharapkan pada penelitian selanjutnya dapat lebih mempertimbangkan faktor-faktor lain seperti tingkat pendidikan, hubungan antara pasien dengan petugas kesehatan maupun keluarga, dan sikap atau emosi pasien yang dapat mempengaruhi kepatuhan pasien dalam mengonsumsi obat.

\section{DAFTAR PUSTAKA}

Anggina, L ; Hamzah, A \& Pandhit. (2010). Hubungan antara dukungan sosial keluarga dengan kepatuhan pasien diabetes mellitus dalam melaksanakan program diet di poli penyakit dalam rsud cibabat cimahi, ISSN: 2086-3098. 1-9.

Anggraini dkk. (2009). Faktor-faktor yang berhubungan dengan kejadian hipertensi pada pasien yang berobat di poliklinik dewasa puskesmas bangkinang periode januari sampai juni 2008. Dipetik 18 September 2012, dari yayanakhyar.wordpress.com: $\quad$ http://yayanakhyar.files .wordpress.com/2009/02/files-of-drsmed-faktor-yangberhubungan-dengan-kejadian hiperte- nsi.pdf.

Albery \& Marcus (2011). Psikologi kesehatan panduan lengkap dan komprehensif bagi studi psikologi kesehatan. Yogyakarta: Palmall.

Almisbah, Z. (2008). Penatalaksanaan hipertensi non farmakologi dalam penurunan angka kejadian stroke. Dipetik 14 Oktober 2012: http:// isjd.pdii .lipi.go. id/admin /jurnal/ed03 084249. pdf.

Arovah, N. (2011). Prinsip pemrograman latihan fisik pada penyakit kronis. $\quad$ Dipetik 2013 : http://staff.uny.ac.id/sites/default/files/13230 0162/5.\%20Prinsip\%20Pemrograman\%20Latihan\%20Fisik\%20 Pada\%20Penderita\%20Penyakit\%20Kronis.pdf.

Azhari. D. (2012). Rawat jalan. Dipetik 2 April 2013: http://30agustus2003 .blogspot.com/2012/04/ rawat-jalan.html.

Azwar, S. (2010). Penyusunan skala psikologi. Yogyakarta: Pustaka Pelajar.

Azwar, S. (2010). Reliabilitas dan validitas. Yogyakarta: Pustaka Pelajar.

Boediono \& Koster, W. (2001). Teori dan aplikasi statistika dan probabilitas sederhana, lugas, dan mudah dimengerti. Bandung: PT Remaja Rosdakarya.

Budiman dkk. (2010). Analisis faktor yang berhubungan dengan kepatuhan minum obat pasien TB paru pada fase intensif di rumah sakit umum cibabat cimahi. Dipetik 15 Desember 2012: http://www.stikesayani.ac.id /publikasi/e-journal/pdf/Jurnal\% 20Agustus\%202010.pdf.

Budiman, B., Hafiz, A. (2012). Epistaksis dan hipertensi : adakah hubungannya?, 1(2), 75-79.

Carpenito. (1998). Diagnosa keperawatan aplikasi pada praktik klinis Eedisi 6. Jakarta: Buku Kedokteran EGC.

Chaplin, J.P. (2004). Kamus lengkap psikologi. Jakarta: PT RajaGrafindo Persada.

Darusman. (2009). Perbedaan Perilaku Pasien Diabetes Mellitus Pria dan Wanita dalam Mematuhi Pelaksanaan Diet. Berita kedokteran masyarakat, 25(1), 31-33. 
Davison, G., Neale, J., Kring, A. (2010). Psikologi abnormal edisi 9. Jakarta: RajaGrafindo Persada.

Departemen Pendidikan Nasional. (2008). Kamus besar bahasa indonesia pusat bahasa edisi keempat. Jakarta: PT Gramedia Pustaka Umum.

Dhewi, G., Armiyati, Y., Supriyono, M. (2012). Hubungan antara pengetahuan, sikap pasien, dan dukungan keluarga dengan kepatuhan minum obat pada pasien tb paru di bkm pati. Dipetik 20 Februari 2013: ejournal.stikestelogorejo. ac.id/index.php/ilmukeperawatan/.../116.

Dimyanti, V. (2012). Prevalensi hipertensi di indonesia masih tinggi. Dipetik 9 Februari 2013: http://www.jurnas .com/halaman/5/2012-09-11/220768.

Dinas Kesehatan Kota Denpasar. (2011). 10 penyakit utama di puskesmas di kota denpasar tahun 2011. Dipetik 31 Maret 2013: http://www.denpasarkota. go.id/instansi/?cid===QO\&s=menu \&id $=450$.

Dongoran, D. (2007). Hubungan antara arterioskeloris retina dengan fungsi kognitif pada penderita hipertensi (Tesis). Dipetik 18 September $2012 \quad$ : $\quad$ http://eprints.undip.ac.id /16907/1/Daniel_Naek_Hatuaon_Dongoran.pdf.

Friedman, Schustack. (2008). Kepribadian teori klasik dan riset moderen edisi 3. Jakarta: Erlangga.

Handaya, R. (2009). Modul 14, psikofarmakologi, psikologi kesehatan, dan forensic psychology. Dipetik 17 Desember 2012: http://www.google.com/url?sa=t\&rct=i\&q=\&esrc=s\&source=we $\underline{b} \& \mathrm{~cd}=10 \& \mathrm{cad}=\mathrm{rja} \& \mathrm{ved}=\mathrm{CG} 4 \mathrm{QFjAJ} \& u r \mathrm{l}=\mathrm{http} \% 3 \mathrm{~A} \% 2 \mathrm{~F} \% 2 \mathrm{Fkk}$ .mercubuana.ac.id\%2Ffiles\%2F6103414254095014209.doc\&ei $=$ YWjOUMPiBsjirAfgq4DACw\&usg=AFQjCNHCv7Di_ZGK Rp5PXaRVaVkIuyQ\&bvm=bv.1355325884,d.bmk.

Haryati. (2010). Hubungan mekanisme koping dengan tingkat kejadian hipertensi esensial pada masyarakat diwilayah kerja puskesmas seyegan seleman (naskah publikasi). Dipetik $8 \mathrm{Mei}$ 2013: http://id.scribd.com/doc/5788584 2 /hubungan-hipertensiessensial-dengan-mekanisme-koping.

Horne. (2006). Implications for Asthma Treatment: CHEST Official Publication Of America Colledge Of Chest Physicians. Compliance, Adherence, \& Concordance, 130. 65-72.

Indraprasti, D \& Rachmawati, M.A. (2008). Hubungan antara kontrol diri dengan perilaku minum-minuman keras pada remaja laki-laki (skripsi). Dipetik 18 Maret 2012: http://repository.uii.ac.id/320/SK/I/0 /00/000/000784/uii-skripsipsikologi\%20kesehatan\%20-\%20kecanduan-indraprasti\%20$\% 20$ 04320092-4912848072-naskah\%20publikasi.pdf.

Iswati, S. (2008). Pengaruh komitmen profesional, tipe kepribadian, gender terhadap kepuasan kerja akuntan publik. Ekuitas, 12 (1). $36-51$.

Iswanti, D. (2012) Pengaruh terapi perilaku modeling partisipan terhadap kepatuhan minum obat pada klien penatalaksanaan regimen terapeutik tidak efektif di rsjd dr. amino gondo hutomo semarang (tesis). Dipetik 18 Januari 2013: lontar.ui.ac.id/file? file =digital/20300661-T30349...pdf.

Jaya, N. (2009). Faktor-faktor yang berhubungan dengan tingkat kepatuhan pasien dalam minum obat antihipertensi di puskesmas pamulang kota tangerang selatan propinsi banten tahun 2009. Dipetik 6 November 2012 : http://perpus.fkik.uinjkt.ac.id/file_digital/Nandang\%20 Tisna.pdf.
Kartika, K; Hasanat, N. (2008). Dinamika emosi kepatuhan diet pada pasien diabetes mellitus. Jurnal Penelitian Psikologi, 13(1). 1120.

Kartikasari, N. (2012). Faktor resiko hipertensi pada masyarakat desa kabongan kidul, kabupaten rembang (skripsi). Dipetik tanggal 4 Agustus 2013: $\underline{\text { http://ejournal- }}$ s1.undip.ac.id/index.php/medico/article/view/1447/1450.

Katzug. (2001). Farmakologi dasar \& klinik. Jakarta: Salemba Medika.

Kuntjojo. (2009). Psikologi Kepribadian. Kediri: Pendidikan Bimbingan dan Konseling Universitas Nusantara PGRI Kediri.

Lailatushifah, S. (2012). Kepatuhan pasien yang menderita penyakit kronis dalam mengonsumsi obat harian. Dipetik 6 November 2012: fpsi.mercubuana-yogya.ac.id/wp-content/.../NoorKepatuhan...pdf.

Lestari, T (2012). Hubungan psikosisial dan penyuluhan gizi dengan kepatuhan diet pasien diabetes melitus tipe 2 rawat jalan di rsup fatmawati tahun 2012 (skripsi). Dipetik 21 Februari 2013: lontar.ui.ac.id/file?file = digital/20299171-S1981...pdf.

Morisky, D. \& Munter, P. (2009). New medication adherence scale versus pharmacy fill rates in senior with hipertention. American Jurnal Of Managed Care, 15(1): 59-66

Mosjab, M dkk. (2008). Gambaran antara kepatuhan minum obat hipoglikemik oral (oho) dengan kejadian komplikasi kronis (hipertensi, neuropati diabetik, sellulitis dan atau ganggren) pada penderita diabetes mellitus di rt 13-16 desa betro kecamatan sedati kabupaten sidoarjo (laporan studi kasus). Dipetik 28 November 2012: http://elib.fk.uwks.ac.id/asset/archieve Ipenelitian/MINUM\%20OBAT\%20HIPOGLIKEMIK\%20ORAL $\% 20 \% 28 \% 200 H O \% 20 \% 29 . p d f$.

Nafrialdi. (2007). Farmakologi dan terapi edisi 5. Jakarta: Gaya Baru.

Niven, N. (2002). Psikologi kesehatan pengantar untuk perawat dan profesional kesehatan lain. Jakarta: Buku Kedokteran EGC.

Oktaviani,D. (2011). Hubungan kepatuhan minum obat anti tuberkulosis dengan status gizi anak penderita tuberkulosis paru (artikel penelitian). Dipetik 19 September 2012: http://eprints.undip.ac.id/32598/1/396_Dini_ Oktaviani_G2C007023.pdf.

Oliveira, Alfredo dkk. (2012). Association between the 8-item morisky medication adherence scale (mmas-8) and blood pressure control. Bras Cardiol, 99(1). 649-658.

Pangesti, R. (2013). Faktor-faktor yang mempengaruhi kepatuhan diet pada penderita asam urat di puskesmas mandiraja 1 kabupaten banjarnegara provinsi jawa tengah (skripsi). Dipetik 6 Maret 2013: http://digilib.ump. ac.id/gdl.php?mod=browse\&op=read\&id=jhptump-arina asripa$\underline{828}$.

Pinel, J. (2009). Biopsikologi edisi ketujuh. Yogyakarta : Pustaka Pelajar.

Pratiwi, D. (2011). Pengaruh konseling obat terhadap kepatuhan pasien hipertensi di poliklinik khusus rsup dr. m. djamil padang. Dipetik 18 September 2012 : http://pasca.unand.ac.id /id/wpcontent /uploads /2011/09/ ARTIKEL4.pdf.

Pujianto. (2008). Faktor sosio ekonomi yang mempengaruhi kepatuhan minum obat antihipertensi. KESMAS, 3(3). 139-144. 
Puspita, R. (2009). Gaya hidup mahasiswa penderita hipertensi (skripsi). Dipetik $20 \quad$ Mei 2012: http://etd.eprints.ums.ac.id/3618/1/F100030148.pdf.

Putra, R. (2010). Faktor psikologis yang mempengaruhi kondisi medis. Dipetik 6 Desember 2012 : http://id.scribd.com /doc/102666975/Refrat.

Ramadona, A. (2011). Pengaruh konseling obat terhadap kepatuhan pasien diabetes millitus tipe 2 di poliklinik khusus rumah sakit umum pusat dr. m. jamil padang. Dipetik 9 Mei 2013: http://pasca.unand.ac.id/id/wp-

content/uploads/2011/09/ARTIKEL-ADE-RAMADONAS.Farm-Apt-082 1213056.pdf/.

Rampengan, S. (2007). Krisis hipertensi, hipertensi emergensi dan hipertensi urgensi. BIK Biomed, 3 (4). 163-168.

Ratnaningtyas, Y., Djatmiko, W. (2011). Hubungan kepribadian tipe d dengan kejadian hipertensi di rsud prof. dr. margono soekardjo. Mandala of Health,5 (2).

Raufina, S. (2012). Perbedaan motivasi kerja pns ditinjau dari kepribadian tipe a dan tipe b. Dipetik 14 Oktober 2012 : repository.gunadarma.ac.id/ bitstream/.../3573 /.../jurnal\%20finapdf.p...Jenis File: PDF/Adobe Acrobat.

Riduwan \& Sunarto. (2010). Pengantar statistika untuk penelitian pendidikan, sosial, ekonomi, komunikasi, dan bisnis. Bandung: Alfabeta.

Robbins, S. (2006). Perilaku organisasi edisi kesepuluh. Jakarta. Indeks.

Rosyid, F., Efendi, N. (2011). Soft skill and character building, Hubungan kepatuhan diet rendah garam dan terjadinya kekambuhan pada pasien hipertensi di wilayah puskesmas pasongsongan kabupaten sumenep madura. Surabaya: Universitas Muhammadiyah Surabaya.

Santrock, J. (2002). Life-Span Development Perkembangan Masa Hidup. Jakarta. Erlangga.

Sanusi, S. (2005). Beberapa uji validitas dan reliabilitas pada instrumen penelitian, 113-116.

Sari, D., Arrum, D. (2006). Stres dan koping perawat kepribadian tipe a dan kepribadian tipe $\mathrm{b}$ di ruang rawat inap rsu. dr. pirngadi medan. Jurnal Keperawatan Rufaidah Sumatera Utara, 2(1). 917.

Siam, A. (2011). Asuhan keperawatan pada pasien tb paru. Dipetik 9 Februari

2013:

http://astrinurlaelasiam.blogspot.com/search?updated$\underline{\min }=2011010 \quad 1 T 00: 00: 0008: 00 \& u p d a t e d-\max =2012-01-$ 01T00:00:00-08:00\&max-resul ts=14.

Siregar, S. (2013). Statistik parametrik untuk penelitian kuantitatif. Jakarta: Bumi Aksara.

Sugiyono. (2012). Statistik untuk penelitian. Bandung: CV Alfabeta.

Suhartini, B. (2009). Pemahaman konsep sehat anak terhadap kepatuhan berobat. Dipetik 14 Desember 2012: http://staff.uny.ac.id/sites/default/files/ 131655987/PEMAHAMAN\%20KONSEP\%20SEHAT\%20AN AK\%20TERHADAP_0.pdf.

Suryabrata. (2000). Metodologi penelitian edisi 1, Cetakan ke-13. Jakarta: PT Raja Grafindo Persada.

Suprianto, dkk. (2009). Hubungan dukungan sosial keluarga dengan kepatuhan menjalankan program pengobatan pasien hipertensi di urj jantung rsu. dr. soetomo Surabaya. Jurnal Keperawatan, 2(2). 8-10.
Susalit, dkk. (2001). Buku ajar ilmu penyakit dalam jilid II edisi 3. Jakarta: Balai Penerbit FKUI.

Sutanto, E., Djohan, L. (2006). Pengaruh persepsi akan dimensi desain organisasi dan tipe kepribadian terhadap tingkat stres karyawan pt. internasional deta alfa mandiri. Jurnal Manajemen dan Kewirahusahaan, 8(1). 25-39.

Sutrisno Hadi. (2000). Statistik 2. Yogyakarta : Andi Offset.

Taylor. (2009). Health psychology. USA: McGraw-Hill.

Tovar, E. (2007). Relationships between psychosocial factors and adherence to diet and exercise in adults with type 2 diabetes (disertasi). Dipetik $24 \quad$ Februari 2013 : http://repositories.tdl.org/utmbir/bitstream/handle/2152.3/196/DISSERTATION _E_GRESSLE_2007-1.pdf?seq uence $=1$.

Wibowo, R. Soedibyo, S. (2008). Kepatuhan berobat dengan antibiotik jangka pendek di poliklinik umum departemen ilmu kesehatan anak rumah sakit dr. cipto mangunkusumo Jakarta. Sari Pediatri, 10(3). 171-176.

Wijayanti, M. (2012) Hubungan konsumsi lemak dan senam dm dengan kadar kolesterol ldl pada penderita diabetes melitus rawat jalan di rsup sanglah denpasar. Denpasar: Politeknik Kesehatan Denpasar.

Wilcox, L. (2012). Psikologi kepribadian, analisis seluk-beluk kepribadian manusia. Yogjakarta: IRCiSoD.

Wuryanto, M. (2008). Tingkat kepatuhan penderita malaria vivax dalam minum obat serta faktor yang mempengaruhinya (studi pada penderita malaria vivax di kabupaten banjarnegara tahun 2005). Jurnal Promosi Kesehsatan Indonesia, 3(1). 24-30.

Yasin, D., Rohman M., Supriati, L. (2012) Analisis faktor-faktor yang berhubungan dengan kepatuhan minum obat pada pasien hipertensi di poliklinik jantung rumah sakit umum daerah de. saiful anwar malang (majalah kesehatan $f k u b$ ). Dipetik 25 Agustus $\quad 2013 \quad$ : $\quad$ http://fk.ub.ac.id/ artikel/id/filedownload/keperawatan/dudella.pdf.

Zainuddin. (2000). Metodologi penelitian. Surabaya: Univ. Airlangga. 